\title{
CAREX DISPERMA DEWEY VERSUS CAREX LOLIACEA L. (CYPERACEAE): DISTRIBUTION DYNAMICS AND CONSERVATION STATUS IN POLAND
}

\author{
PAWEŁ PAWLIKOWSKI \\ Department of Plant Ecology and Environmental Conservation, \\ University of Warsaw \\ Al. Ujazdowskie 4, 00-478 Warszawa, Poland \\ e-mail: p.pawlikowski@uw.edu.pl
}

(Received: October 21, 2009. Accepted: May 31, 2010)

\begin{abstract}
Carex disperma Dewey reaches its south-eastern range limit in north-eastern Poland. It has often been confused with Carex loliacea L. In this paper the diagnostic features of both species are presented. A total of about 47 reliable localities of $C$. disperma were recorded within the present borders of Poland. Less than one-third of them have only been confirmed recently. They are aggregated in large forest complexes in north-eastern Poland (Romincka, Białowieża, Borki, Augustów and Knyszyn Forests). A list of localities of C. disperma based on herbarium records, credible literature data and the author's own data is provided, as well as maps of distribution of both $C$. disperma and $C$. loliacea in Poland. The existence of $C$. disperma $\times C$. loliacea hybrid was not confirmed. Considering the number of localities, dynamics and population sizes of both species it is clear that $C$. disperma is a species with higher conservation value than $C$. loliacea. Unlike $C$. disperma, the latter species is not threatened with extinction in Poland. The resources of $C$. disperma are very limited and the species needs conservation measures such as creating sufficiently large nature reserves where appropriate hydrological conditions can be maintained.
\end{abstract}

KEY WORDS: Carex disperma, Carex loliacea, Cyperaceae, distribution, threatened species, conservation status, range limit, Poland.

\section{INTRODUCTION}

Carex disperma Dewey (=C. tenella Schkuhr, non Thuill.) and Carex loliacea L., are circumboreal species bound to the taiga zone. Both species reach their southwestern range limit in Poland and in other countries of the Baltic Sea basin (Norway, Sweden, Kaliningrad region of Russia, Lithuania, Belarus) (Hultén, Fries 1986).* In Poland, they occur only in the north-eastern part of the country. Their localities were recorded almost exclusively in forest complexes that retained primeval features (Zając and Zajac 2001). C. disperma and C. loliacea are considered threatened in Poland and both are given the 'vulnerable' species status (Pawlikowski 2001a, b, Zarzycki and Szeląg 2006). The species are also listed as threatened in the neighbouring Kaliningrad region of Russia (Ingelög et al. 1993).

\footnotetext{
* Moreover, isolated localities of Carex loliacea were recorded in Eastern Carpathians in Romania (Şerbănescu 1966). Although these localities were not given on the map of distribution presented by Hultén and Fries (1986), they are certain and confirmed by the specimens in Polish herbaria (KRAM, POZ and WA).
}

In Poland, the data on the distribution of Carex disperma are often out of date. The majority of localities have not been confirmed for at least 30 years (e.g. Sokołowski 1988a), or since the beginning of the 20th century (Abromeit et. al. 1931-1940). In the "Distribution Atlas of Vascular Plants in Poland" (Zając and Zając 2001), the majority of localities were assigned the 'not confirmed' status. Thus, very little is known about the species distribution dynamics in Poland or contradictory information is supplied. According to Schweitzer and Polakowski (1994), in the Romincka Forest, Carex disperma still occurs in two localities only (and C. loliacea is extinct), which is contrary to the information provided by Sokołowski (1988a) and Pawlikowski (2001a, b). Sokołowski (1988a) listed a total of 11 localities of C. disperma in Poland, whereas in the "Flora von Ost- und Westpreussen" (Abromeit et al. 1931-1940), solely from two forest complexes (Romincka Forest and Borki Forest) about 16 occurrences of the species are given.

Carex disperma and C. loliacea are likely to be confused with each other (e.g. Reznicek and Ball 1981) and some of the existing data on the species distribution can be invalid. Additionally, in the 19th century the names Carex tenella Schkuhr 
(the former name for $C$. disperma) and $C$. loliacea $\mathrm{L}$. were treated as synonyms by many authors (e.g. Ledebour 1853). Consequently, apart from few data from the former East Prussia (Abromeit et al. 1931-1940), there are no reports of C. disperma in the 19th century from the territory of contemporary Poland. Only Carex loliacea was included in many contemporary Central-European botanical monographs (e.g. Kluk 1805; Rostafiński 1872; Potonié 1889).

The aim of this study is to verify the distribution and dynamics of Carex disperma in Poland, in relation to $C$. loliacea. In order to assess the conservational status of the species, current and up to date information on the resources are needed.

\section{MATERIAL AND METHODS}

\section{Taxonomical remarks}

Carex disperma Dewey (=C. tenella Schkuhr) and Carex loliacea L. are tiny, slender sedges that form small mats or loose tussocks. They have inflorescences with few spikes, each with few flowers only. According to the approach accepted by the majority of authors, $C$. disperma (as well as $C$. loliacea) belong to the subgenus Vignea (Egorova 1999), which groups species of bisexual spikes and distigmatic flowers. Their inclusion to the particular section is a matter of disagreement. Traditionally, after Kükenthal (1909), both species used to be included in the section Tenuiflorae (e.g. Hegi 1967-1980), but Ohwi (1936) had excluded $C$. disperma from the above section and proposed creating a new, monotypic section Dispermae. The classification of both species into separate sections within the Vignea subgenus (e.g. Toivonen and Timonen 1976; Egorova 1999) was confirmed later by the DNA sequence analyses (Ford et al. 2006).

Carex disperma and C. loliacea are likely to be confused with each other. Characteristics useful in distinguishing both species are presented in Table 1.

\section{Methods}

Specimens of Carex disperma, C. loliacea and their hybrids were searched for in Polish herbarium collections. This was supplemented by literature survey and field exploration of suitable habitats in the years 1998-2009. A list of all the localities of $C$. disperma in Poland is provided, as well as the map of distribution of $C$. disperma and $C$. loliacea using 10×10 km ATPOL grid square system (Zając 1978). Specimens collected during the field survey were deposited at the Faculty of Biology Herbarium (WA) at University of Warsaw.

\section{RESULTS}

So far, about 47 localities of Carex disperma have been reported from Poland (and about 150 localities of $C$. loliacea). The localities of $C$. disperma were recorded almost exclusively in large forests with primeval features (Fig. 1). These were: Borki (about 21 localities), Romincka (9), Białowieża (10), Knyszyn (3) and Augustów Forests (2). Fourteen of the localities are presently confirmed. The majority of the localities confirmed after the year 2000 were situated in Romincka Forest (6 localities), whereas in the remaining forest complexes: Białowieża, Borki, Knyszyn and Augustów Forests, a total of eight localities (respectively: 4, 2, 1, 1) were confirmed or discovered. The most abundant populations (each covering more than 20 $\mathrm{m}^{2}$ ) were recorded in a peatland south-east of Czarnowo Średnie settlement in Romincka Forest, in "Boczki" reserve in Borki Forest, and in "Kozi Rynek" reserve in Augustów Forest. In eight localities the species resources were very small and $C$. disperma covered areas of less than $5 \mathrm{~m}^{2}$. Particularly small were populations in the Białowieża Forest. Among the localities that should be considered extinct is the locality in Dylewo Hills (the westernmost locality in Poland, which indicated the western limit of $C$. disperma distribution in Europe), as well as some localities in Borki and Romincka Forests.

Carex loliacea was recorded quite often in almost all the forest complexes listed (Fig. 2), particularly in Augustów Forest, where $C$. disperma was hardly present. Moreover, the species was noted in several other places. Due to the presence of these scattered, isolated localities (e.g. in Napiwoda-Ramuki Forest and Pisz Forest in Warmia and Masuria Province, Suwałki Scenic Park in Podlasie Province, Sobibór Forest and near Konstantynów in Lublin Province), the total range of distribution of $C$. loliacea in Poland is significantly broader than that of $C$. disperma. Considering the $10 \times 10 \mathrm{~km}$ squares in the "Distribution Atlas of Vascular Plants in Poland" (Zając and Zając 2001), C. disperma was recorded in 17 squares only, while the localities of $C$. loliacea were situated in 41 squares.

TABLE 1. Characteristics differentiating Carex disperma and Carex loliacea.

\begin{tabular}{|c|c|}
\hline Carex disperma & Carex loliacea \\
\hline $\begin{array}{l}\text { perigynia beaked with a short beak, glabrous, faintly nerved, or appearing } \\
\text { nerveless, glossy }\end{array}$ & $\begin{array}{l}\text { perigynia beakless or hardly beaked, distinctly nerved and therefore } \\
\text { appearing ribbed, dull }\end{array}$ \\
\hline (0)1-2(4) perigynia in single spike & (1)2-7(12) perigynia in single spike \\
\hline inflorescence $2-4 \mathrm{~cm}$ long & inflorescence $1-3 \mathrm{~cm}$ long \\
\hline stems filiform, arch-like decumbent & $\begin{array}{l}\text { stem rather rigid, usually erect when flowering and during early fruit } \\
\text { development }\end{array}$ \\
\hline intervals between lower spikes in inflorescence usually very unequal & intervals between lower spikes in inflorescence usually more-less similar \\
\hline staminate flower(s) present at the apex of one spike at least & all spikes with pistillate flowers at the apex \\
\hline
\end{tabular}



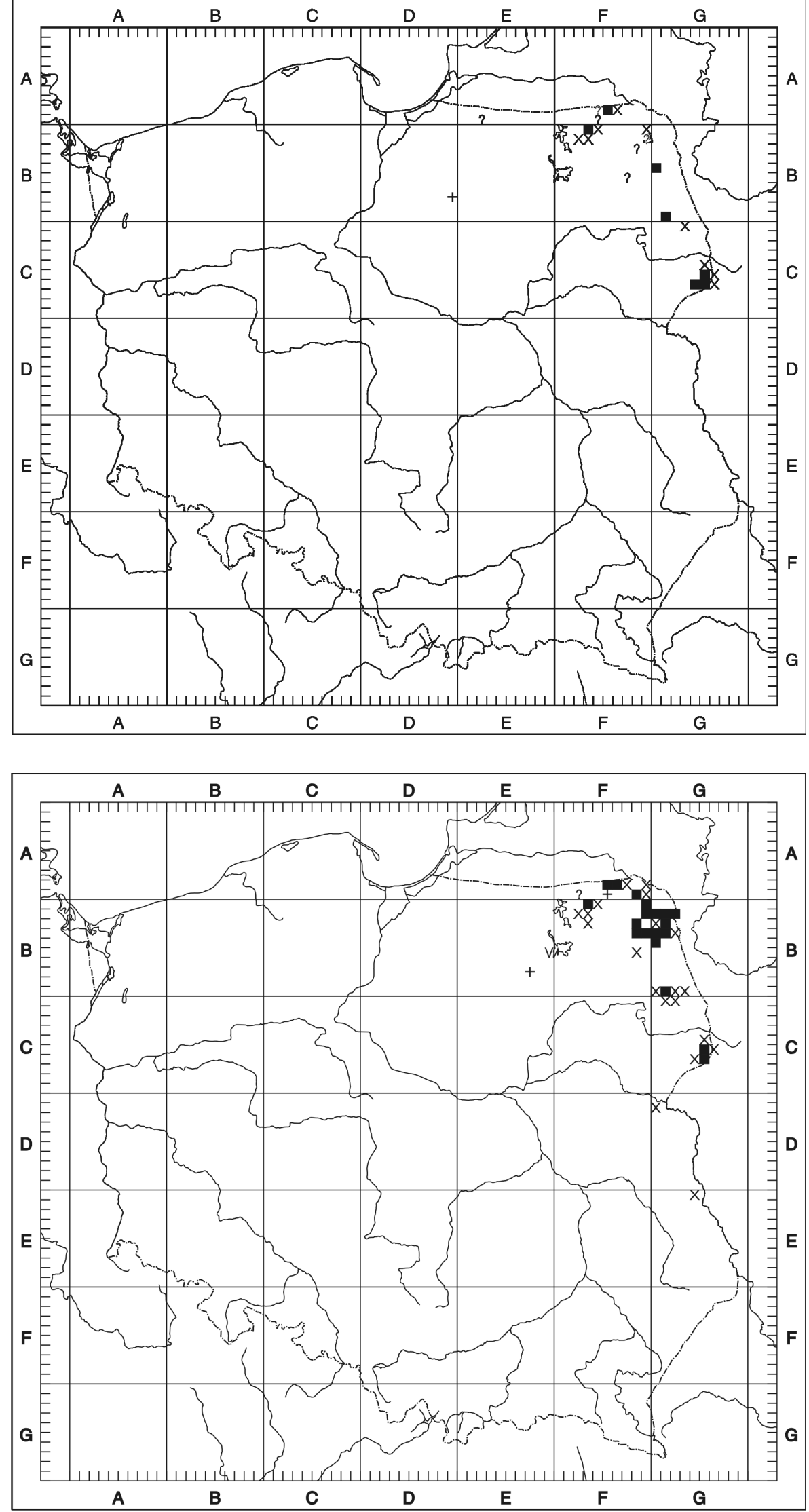

Fig. 1. Distribution of Carex disperma Dewey in Poland. - - locality confirmed after the year 2000; $\mathrm{x}$ - unconfirmed locality; +- extinct locality; ? - uncertain locality.

Fig. 2. Distribution of Carex loliacea L. in Poland. - - locality confirmed after the year 2000; $x$ - unconfirmed locality; + - extinct locality; ? - uncertain locality; $\mathrm{v}$ - locality of the possible hybrid between $C$. loliacea and C. curta.

Carex disperma, Carex loliacea and their hybrids in Polish herbarium collections

Apart from the two exsiccata issues (leg. J. Mądalski 1936 and leg. W. Gugnacka-Fiedor 1975), Carex disperma specimens were encountered in three herbarium collections only (29 sheets in BIL, OLS and TRN), and Carex loliacea - in 13 collections (167 sheets in BIL, BSG, KRA, KRAM, KTU, LOD, LUB, OLS, POZ, TRN, WA, WRSL and WSRP; abbreviations of the names of herbaria follow Mirek et. al. 1997). All the encountered errors were C. loliacea determined as $C$. disperma (but never vice versa). 
Moreover, all the specimens determined as hybrids between $C$. disperma and $C$. loliacea, belonged to either $C$. disperma or C. loliacea.

\section{List of reliable localities in Poland}

All the data sources relating to Carex disperma occurrences presented on the map (Fig. 1) are listed below. In the case of $C$. loliacea, a detailed list of localities is not presented as the number of localities and literature sources pertaining to them is too high. The map (Fig. 2) is based on herbarium specimens, literature data (e.g. Abromeit et al. 1931-1940; Koppe and Koppe 1937; Czerwiński 1986; Magiera 1986; Sokołowski 1988 b and literature cited; Schweitzer, Polakowski 1994; Pawlikowski 2001a and literature cited, 2008a, b; Jutrzenka-Trzebiatowski et al. 2002) and my own unpublished information from the years 1999-2009 .

Every locality described below was assigned an appropriate ATPOL grid square (Zając and Zając 2001). Abbreviations used: [B] - Białowieża; $[\mathrm{CzS}]$ - the village of Czarnowo Średnie; div. - number of the forest division [G] - Gołdap; [H] - Hajnówka; [K] - Kruklanki; [KO] Kowale Oleckie; NP. - National Park; res. - nature reserve, NC - not confirmed; s. - settlement; v. - village; ! - Paweł Pawlikowski.

\section{DYLEWO HILLS}

DB79: $1 \mathrm{~km}$ SE of Owczarnia s. next to the v. of Pietrzwałd (TRN: leg. J. Hutorowicz 1957), most probably extinct due to a habitat desiccation (!2001).

\section{ROMINCKA FOREST}

FA85: ca. $3 \mathrm{~km}$ west of [CzŚ] and ca. $3 \mathrm{~km}$ north-east of the v. of Jurkiszki, [G] comm. (Grütter 1897; Abromeit et al. 1931-1940 - div. 35), NC (! 1999-2000) - this locality is probably identical with the "Jurkiszki" site (Polakowski 1963); $1 \mathrm{~km}$ north-west of [CzŚ], [G] comm. (Grütter 1897; Abromeit et al. 1931-1940 - div. 49, WA: leg. ! 2000, ! 1999-2003 - ca. $5 \mathrm{~m}^{2}$; since then not confirmed due to damaging forestry practices - clear cutting and drainage); $0.5 \mathrm{~km}$ north-west of [CzŚ], [G] comm. (Grütter 1897; Abromeit et al. 1931-1940: div. 49, WA: leg. ! 2000 - ca. $4 \mathrm{~m}^{2}$ ); $1 \mathrm{~km}$ west of [CzŚS], [G] comm. (Grütter 1897; Abromeit et al. 1931-1940 - div. 33); northern part of "Mechacz Wielki" res., south of [CzŚ], [G] comm. (Koppe and Koppe 1931; WA: leg. ! 2000 - ca. $20 \mathrm{~m}^{2}$ ); south-western part of "Mechacz Wielki" res., north of the v. of Galwiecie, [G] comm. (WA: leg. ! 2000 - ca. $3 \mathrm{~m}^{2}$ ); $1.5 \mathrm{~km}$ south-east of [CzŚ], [G] comm. (WA: leg. ! 2002 - ca. 25 $\mathrm{m}^{2}$ ); this locality is probably identical with the "ca. $2 \mathrm{~km}$ östlich von Gross Jodupp" site (Schweitzer, Polakowski 1994); $2 \mathrm{~km}$ north of Czarne Lake, north-east of the v. of Budwiecie and north of the v. of Pluszkiejmy, [G] comm. (Grütter 1897; Abromeit et al. 1931-1940 - div. 4, Polakowski 1963, BIL: leg. A. Kawecka 1969, Sokołowski 1988a, WA: leg. ! 2000 - less than $\left.0.5 \mathrm{~m}^{2}\right)$; southern part of "Boczki" res., Dubeninki comm. (WA: leg. ! 2001 - ca. $\left.2 \mathrm{~m}^{2}\right)$;

FA86: west part of "Żytkiejmska Struga” res., Dubeninki comm. (Lettau 1902; Abromeit et al. 1931-1940: div. 53/54), NC (! 2005-2008); this locality is probably identical with the "ca. $3 \mathrm{~km}$ nordöstlich des Forsthauses" (Schweitzer, Polakowski 1994).

\section{BORKI FOREST}

FB03: $1 \mathrm{~km}$ south-east of a small lake near Budziska Leśne s., [K] comm. (Koppe and Koppe 1937 - div. 43); 1 $\mathrm{km}$ east of a small lake near Budziska Leśne s., [K] comm. (Koppe and Koppe 1937 - div. 59); 1.5 km south of Olszówka s., [K] comm. (Koppe and Koppe 1937 - div. 9); east of Góra Czarcia hill and north of "Borki" res., three localities in neighbouring depressions, [K] comm. (Koppe and Koppe 1937 - div. 136, 146, 157); eastern part of the "Borki" res. and areas adjacent to the north-east and east, several (ca. 4) localities in separate depressions (they are treated together as the historical locations are imprecise), [K] comm. (Abromeit 1910; Abromeit 1928, Abromeit et al. 1931-1940 - div. 120, 205, 206; OLS: leg. B. Polakowski 1956, 1974, 1986, Polakowski 1961, KTU, KRA, KRAM, LOD, LUB, POZ, TRN, WA, WRSL: leg. W. Gugnacka-Fiedor 1975, ! 1999-2001; WA: leg. ! 1999 - ca. $20 \mathrm{~m}^{2}$ in two separate localities); western part of "Borki" res. and areas adjacent to the north-west and west, at least two localities, [K] comm. (Abromeit 1918; Abromeit 1928; Abromeit et al. 1931-1940 - div. 127 or 129; Polakowski 1961); between Rogonie s. and Pilwąg Lake, north-west of Łaźno Lake, [KO] comm. (Abromeit 1910; Abromeit et al. 1931-1940 - div. 25); north of two small lakes north of Pilwąg Lake, [KO] comm. (Koppe and Koppe 1937 - div. 60A);

FB04: $1 \mathrm{~km}$ north of Olszanka s., [KO] comm. (Koppe and Koppe 1937 - div. 76); 1 km north of Ślepak Lake, north-east of the v. of Szwałk, [KO] comm. (Abromeit 1910; Abromeit et al. 1931-1940 - div. 73); $1 \mathrm{~km}$ north of Ciche Lake, [KO] comm. (Abromeit 1910; Abromeit et al. 1931-1940, Koppe and Koppe 1937 - div. 69);

FB12: $1.5 \mathrm{~km}$ east of Knieja Łuczańska s., [K] comm. (Abromeit 1928; Abromeit et al. 1931-1940 - div. 203);

FB13: south of Zamoście s., west of the northern part of Litygajno Lake (Abromeit 1910 - div. 57); south-west of Litygajno Lake, [K] comm. (TRN: leg. Phoeodovius 1897, Abromeit 1899; Abromeit et al. 1931-1940 - div. 23); east of Dubinek Lake, [K] comm. (Abromeit et al. 1931-1940div. 28).

\section{AUGUSTÓW FOREST}

GB09: Wigry NP., Wiatrołuża (Kaletnik) river valley east of the v. of Lipniak and south of the v. of Dębowo (BIL, leg. A. Sokołowski 1976; Sokołowski 1988a, 1990b, Jutrzenka-Trzebiatowski et al. 2002), NC (! 2009);

GB40 south-western margin of "Kozi Rynek" res., Sztabin comm. (BIL: leg. A. Sokołowski 1963, Sokołowski 1965, 1969, 1988a, WA: leg. ! 2001, ! 2001, 2009 - ca. $25 \mathrm{~m}^{2}$ ).

\section{KNYSZYN FOREST}

GB03: Stare Biele res., Szudziałowo comm. (Sokołowski 1985, 1988a, 1995b, BIL: leg. A. Sokołowski 1979);

GB90: peatland in the eastern part of "Jesionowe Góry" res., Czarna Białostocka comm. (Sokołowski 1985, 1995b, WA: leg. ! 2002 - ca. $4 \mathrm{~m}^{2}$ ); peatland in the southern part of "Jesionowe Góry" res., Czarna Białostocka comm. (Sokołowski 1985, 1995b), NC (! 2001-2002).

\section{BIALOWIEŻA FOREST}

GC45: 1 km east of Gruszki s., div. 81A, Narewka comm. (BIL: leg. J. Żurowski 1974, Sokołowski 1988a, 1995a);

GC55: "Kosy Most" site, div. 160D, Narewka comm. (BIL: leg. A. Sokołowski 1971, Sokołowski 1988a, 1989a, Sokołowski 1995a); [B] NP., Hwoźna river valley, div. 191A, [B] comm. (D. Wołkowycki, pers. comm. 2009); 
GC56: [B] NP., "Augustowski Sad" site, div. 345B, 345C and 346C, [B] comm. (BIL: leg. A. Sokołowski 1965, 1966, 1979, Sokołowski 1981, 1988a, 1995a; [B] NP., div. 404/405 on the present state border, [B] comm. (Paczoski 1930);

GC64: north-eastern part of "Michnówka" res., div. 572B, [H] comm. (BIL: leg. A. Sokołowski 1975, Sokołowski 1995a, 1988a, 1998, WA: leg. ! 2001 - ca. $1 \mathrm{~m}^{2}$ );

GC65: "Berezowe Lado" peatland, div. 543B, [H] comm. (Magiera 1986, WA: leg. ! 2001 - ca. $1 \mathrm{~m}^{2}$ ); "Władysław Szafer" res., div. 444D, [H] comm. (BIL: leg. A. Sokołowski 1963, Sokołowski 1995a; J. Chojnacki pers. comm. 1999; ! 1999-2001 - ca $4 \mathrm{~m}^{2}$ ); $1.5 \mathrm{~km}$ north-east of Podcerkwy s., div. 524 and 548, [B] comm. (Paczoski 1930);

GC66: part of „Wysokie Bagno” res. adjacent to the present state border, div. 477, [B] comm. (KRA, KRAM, POZ, TRN, WA: leg. J. Mądalski 1936, BIL: leg. A. Sokołowski 1974 - see Sokołowski 1988a, 1989a, Sokołowski 1994, 1995a, 1999), NC (! 2001-2002).

\section{Uncertain information on localities in Poland}

In his work, Czerwiński (1967) reported only Carex disperma, which is more rarely encountered than C. loliacea. Considering the lack of herbarium specimens collected by this author, these and other imprecise localities mentioned by the author of the paper should be considered uncertain. These are: Gołdap (FA84?), Sobolewo (FB19), Jaśki (FB28), Czarna Wieś (nowadays Czarna Białostocka, GB91), Jastrzębna (GB41) (Czerwiński 1967), and Szeskie Hills (FA94? - Czerwiński 1978) and Biebrza National Park (FB58? - Czerwiński 1991). Moreover, the species is listed in the phytosociological table of Polakowski (1962) from the locality near the village of Wągniki (Wangnik) (Górowo Iławieckie comm. - EA92), but due to the lack of herbarium specimens the above mentioned locality should be considered uncertain as well.

\section{DISCUSSION}

Schweitzer and Polakowski (1994), who analysed the distribution dynamics of rare plant species in the present Warmia and Masuria Province, pointed out that although Carex loliacea was a more widely distributed species than C. disperma before the World War II, it decreased significantly and now $C$. disperma is a more common species. My results showed that $C$. disperma was much scarcer in Poland than $C$. loliacea. At the same time it should be pointed out that there are more reliable, historical records of $C$. disperma in Poland than it was previously thought (Sokołowski 1988a; Pawlikowski 2001b).

Delin (1992) classified C. disperma (as well as C. loliacea) as a species occurring in ancient tree stands that have persisted for the last hundreds of years. He indicated that forest management activities in such forests, especially when accompanied by draining, led to the extinction of the species. This is in agreement with Trass et al. (1999), who listed $C$. disperma and $C$. loliacea among hemerophobic species, specific to primaeval wet forests. Sokołowski (1988a) determined the reasons for Carex disperma and $C$. loliacea decline: lowering of the water table by draining as well as clear-cutting of the peatland forests.
Wet alder forests in the vicinity of several localities of $C$. disperma are still subject to clear-cutting, and disturbed hydrological conditions lead to eutrophication in some places. One of the populations of the species in Romincka Forest (near the village of Czarnowo Średnie) disappeared within three years as a consequence of clear-cutting and draining of the wet alder forest in the year 2000. The conservation of both species requires the preservation of the natural conditions, first of all undisturbed hydrology with high groundwater level in wet forests they inhabit. As the main conservation measure, Sokołowski (1988a) indicated the establishment of sufficiently large nature reserves in order to preserve the hydrological conditions. This is particularly essential in the case of localities in Romincka Forest that are still outside the nature reserves.

The majority of historical localities in Borki Forest were not confirmed after World War II, although the area was surveyed in order to confirm them. Their status is uncertain. The estimation of the species dynamics in Poland is difficult as the historical data from the present Podlasie Province are very scarce. Therefore only several localities can be considered extinct or most probably extinct. Applying the IUCN definitions of categories of threat (IUCN...2008), Carex disperma should be given EN (endangered) category, as the number of individuals does not exceed 2500 and the number of individuals in the largest population does not exceed 250. At the same time, Carex loliacea, with the number of individuals exceeding 10000 , should not be considered threatened at all. It represents NT (near threatened) category because of the observed small decline in population size and number of localities.

Hybrid plants Carex disperma $\times$ C. loliacea were reported from Borki Forest at the end of the 19th century (Abromeit et al. 1931-1940). The above mentioned hybrid is listed in the monographs of the Polish flora (e.g. Raciborski and Szafer 1919; Szafer et al. 1953; Rutkowski 2004) as well. Nevertheless, I did not encounter such hybrid plants in Polish herbarium collections and during my field survey. Moreover, on the basis of leaf epidermis ultrastructure analyses, Toivonen (1981) denied the existence of such a hybrid and concluded that reports from the former East Prussia (at present Warmia and Masuria region) were invalid. Egorova (1999) also did not list the above mentioned hybrid combination. Thus, the inclusion of the $C$. disperma $\times C$. loliacea hybrid in Polish flora monographs should be considered unfounded.

The existence of other hybrids between Carex disperma and species representing other sections, which were reported from the present Russian part of the Romincka Forest (C. remota, C. curta - Abromeit et al. 1931-1940) seems to be doubtful. This is contrary with the entirely sterile within-section hybrid between $C$. loliacea and C. curta (Toivonen 1981) that was reported from north-eastern Poland by Abromeit et al. (1931-1940) since the plants showing intermediate features between the two species were encountered during my herbarium surveys as well (specimens in OLS, leg. Z. Endler 1981 in Skaliskie Forest).

\section{ACKNOWLEDGMENTS}

I am grateful to Prof. Adam Zając for providing me with the ATPOL database information, the Curators and the 
Staff of Polish herbaria for the loan of herbarium specimens and their hospitality during my visits, and Dr. Dan Wołkowycki for making his unpublished data on the locality of Carex disperma in Białowieża National Park available to me. I would like to thank Prof. Barbara SudnikWójcikowska for her support and supervision of my Masters thesis, which dealt with Carex disperma and Carex loliacea in the years 2001-2002.

\section{LITERATURE CITED}

ABROMEIT J. 1899. Bericht über die 37. Jahresversammlung des Preussischen Botanischen Vereins am 4. Oktober $1898 \mathrm{zu}$ Thorn. Schr. phys.-ökon. Ges. Königsberg 40: 52-86.

ABROMEIT J. 1910. Systematisches Verzeichnis der wichtigeren im Kreise Lötzen und seinen Grenzgebieten 1908 und 1909 beobachteten Pflanzen. Jahres-Ber. Preuss. Bot. Ver. 1909: 49-67.

ABROMEIT J. 1918. Bericht über die wissenschaftlischen Verhandlungen auf der 53. Jahresversammlung in Heiligenbeil am 2. Oktober 1915 sowie über die Tätigkeit des Preussischen Botanischen Vereins in den Jahren 1914 und 1915. Schr. phys.ökon. Ges. Königsberg 58: 20-48.

ABROMEIT J. 1928. Neue und bemerkenswertere Pflanzenfunde in Ostpreussen und den benachbarten Gebieten. Schr. phys.ökon. Ges. Königsberg 65(3/4): 182-238.

ABROMEIT J., NEUHOFF W., STEFFEN H. 1931-1940. Flora von Ost- und Westpreussen. Teil 2. Kommissionverlag Gräfe und Unzer, Königsberg, pp. 686-1248.

CZERWIŃSKI A. 1967. Niektóre rzadsze rośliny naczyniowe województwa białostockiego. Cz. I. Fragm. Flor. Geobot. 13: 329-335. (in Polish with English summary)

CZERWIŃSKI A. 1978. Zbiorowiska leśne północno-wschodniej Polski. Zesz. Nauk. Politechn. Białost. 27: 1-326. (in Polish)

CZERWIŃSKI A. 1986. Charakterystyka roślinności Kuriańskiego Bagna. Zesz. Nauk. Politechn. Białost. 53, Nauki Tech. Inż. Środ. 2: 95-112 (in Polish).

CZERWIŃSKI A. 1991. Lasy na torfowiskach w Kotlinie Biebrzy i perspektywy ich rozwoju w aspekcie produkcyjnym i ochrony środowiska. Zesz. Probl. Post. Nauk Roln. 372: 335-370. (in Polish with English summary)

CZERWIŃSKI A. KOŁOS A., MATOWICKA B. 2000. Zbiorowiska leśne. In: Czerwiński A., Kołos A., Matowicka B. (eds), Przemiany siedlisk i roślinności torfowisk uroczyska Stare Biele w Puszczy Knyszyńskiej. Politech. Białost., Białystok, pp. 123-133. (in Polish)

DELIN A. 1992. Kärlväxter i taigan i Hälsingland - deras anpassningar till kontinuitet eller störning. Svensk Bot. Tidskr. 86: 147-176. (in Swedish with English summary)

EGOROVA T.V. 1999. The sedges (Carex L.) of Russia and adjacent states (within the limits of the former USSR). St.-Petersburg State Chemical-Pharmateutical Academy, St.-Petersburg; Missouri Botanical Garden Press, St. Louis, pp. 772.

FORD B.A., IRANPOUR M., NACZI R.F.C., STARR J.R., JEROME C.A. 2006. Phylogeny of Carex subg. Vignea (Cyperaceae) based on non-coding nrDNA sequence data. Systematic Botany 31(1): 70-82.

GRÜTTER M. 1897. Beitrag zur Kenntnis der Flora des Kreise Oletzko und Goldap. Schr. phys.-ökon. Ges. Königsberg 38: 48-51.

HEGI G. (ed.). 1967-1980. Illustrierte Flora von Mittel-europa. Bd. 2. Angiospermae: Monocotyledones 2, Teil 1. Verl. P. Parey, Berlin-Hamburg, pp. 439.

HULTÉN E., FRIES M. 1986. Atlas of north european vascular plants. 1. Koeltz Scientific Books, Königstein, pp. xvi +498.

INGELÖG T., ANDERSSON R., TJERNBERG M. (eds). 1993. Red Data Book of the Baltic Region. 1. Swedish Threatened Species Unit, Uppsala and Inst. Biol., Riga, pp. 95.
IUCN STANDARDS AND PETITIONS WORKING GROUP 2008. Guidelines for Using the IUCN Red List ategories and Criteria. Version 7.0. Standards and Petitions Working Group of the IUCN SSC Biodiversity Assessments Sub-Committee in August 2008. Downloadable from http://intranet.iucn.org/ webfiles/doc/SSC/RedList/RedListGuidelines.pdf.

JUTRZENKA-TRZEBIATOWSKI A., SZAREJKO T., DZIEDZIC J. 2002. Walory florystyczne wybranych obiektów badań geobotanicznych Wigierskiego Parku Narodowego. Acta Bot. Warm. Masur. 2: 63-92. (in Polish with English summary)

KLUK K. 1805. Dykcyonarz roślinny. T. 1, A-E. Drukarnia Xięży Piarów, Warszawa, pp. 214. (in Polish)

KOPPE F., KOPPE K. 1931. Zur Moosflora Ostpreussens. Unser Ostland 1(6): 299-394.

KOPPE F., KOPPE K. 1937. Zur Moosflora Ostpreussens. 2. Schr. phys.-ökon. Ges. Königsberg 69(2-4): 357-382.

KÜKENTHAL G. 1909. Cyperaceae - Caricoideae. In: Engler A. (ed.), Das Pflanzenreich. Regni vegetabilis conspectus. 38. W. Engelmann Verl., Leipzig, pp. 824.

LEDEBOUR C.F. 1853. Flora Rossica. Enumeratio Plantarum in Totius Imperii Rossici. 4, Sumtibus Librariae E. Schweizerbart, Stuttgartiae, pp. 741. (in Latin)

LETTAU A. 1902. Bericht über Exkursionen im Sommer 1900 in den Kreisen Goldap, Stallupönen und Insterburg. Schr. phys.ökon. Ges. Königsberg 42: 36-39.

MAGIERA G.J. 1986. Roślinność i jej przestrzenne rozmieszczenie na torfowisku Berezowe Lado. Zesz. Nauk. Politechn. Białost. 53, Nauki Tech. Inż. Środ. 2: 77-92. (in Polish)

MIREK Z, MUSIAE L., WÓJCICKI J.J. 1997. Polish herbaria. Polish Bot. Stud., Guideb. Ser. 18: 1-116.

OHWI J. 1936 Cyperaceae Japonicae. I. A Synopsis of the Caricoideae of Japan, including the Kuriles, Saghalin, Korea, and Formosa. Memoirs Coll. Sci. Kyoto Imp. Univ., Ser. B 11: 229-530.

PAWLIKOWSKI P. 2001a. Carex loliacea L. Turzyca życicowa. In: Kaźmierczakowa R., Zarzycki K. (eds.), Polska czerwona księga roślin. Inst. Ochr. Przyr. Polish Acad. Sci. and W. Szafer Inst. Bot. Polish Acad. Sci., Kraków, pp. 496-498. (in Polish with English summary)

PAWLIKOWSKI P. 2001b. Carex disperma Dewey. Turzyca szczupła. In: Kaźmierczakowa R., Zarzycki K. (eds), Polska czerwona księga roślin. Inst. Ochr. Przyr. Polish Acad. Sci. and W. Szafer Inst. Bot. Polish Acad. Sci., Kraków, pp. 499501. (in Polish with English summary)

PAWLIKOWSKI P. 2008a. Nowe stanowiska zagrożonych gatunków torfowiskowych roślin naczyniowych i mchów w Suwalskim Parku Krajobrazowym i jego otulinie. Fragm. Flor. Geobot. Polonica 15(1): 43-50. (in Polish with English summary)

PAWLIKOWSKI P. 2008b. Rzadkie i zagrożone rośliny naczyniowe torfowisk w dolinie Kunisianki na Pojezierzu Sejneńskim. Fragm. Flor. Geobot. Polonica 15(2): 205-212. (in Polish with English summary)

POLAKOWSKI B. 1961. Stosunki florystyczno-fitosocjologiczne Puszczy Boreckiej ze szczególnym uwzględnieniem lasów leśnictwa Lipowo i Walisko. Studia Soc. Sci. Torun., Sec. D 5: 1-146. (in Polish with German summary)

POLAKOWSKI B. 1962. Bory świerkowe na torfowiskach (zespół Piceo-Sphagnetum Girgensohnii) w północno-wschodniej Polsce. Fragm. Flor. Geobot. 8(2): 139-156. (in Polish with German summary)

POLAKOWSKI B. 1963. Stosunki geobotaniczne Pomorza Wschodniego. Zesz. Nauk. Wyższ. Szk. Roln. Olszt. 15: 167-249. (in Polish with German Sumary)

POTONIÉ H. 1889. Illustrierte Flora von Nord- und MittelDeutschland. J. Springer Verl., Berlin, pp. 598.

RACIBORSKI M. SZAFER W. (eds). 1919. Flora Polska. Rośliny naczyniowe Polski i ziem ościennych. I. Akad. Umiejętn., Kraków, pp. 427 (in Polish) 
REZNICEK A.A., BALL P.W. 1981. The Sedge Carex loliacea in Eastern North America. The Canadian Field-Naturalist 95(1): 89-92.

ROSTAFIŃSKI J. 1872. Florae Polonicae Prodromus. Verhandl. zool-botan. Gesellsch. in Wien 1872: 81-208.

RUTKOWSKI L. 2004. Klucz do oznaczania roślin naczyniowych Polski niżowej. Wydawn. Nauk. PWN, Warszawa, pp. 814. (in Polish)

SCHWEITZER H.J., POLAKOWSKI B. 1994. Ehemalige und jetzige Verbreitung seltener Gefäßpflanzen in West- und NordPolen. Senckenbergiana biologica 73(1-2): 189-214.

SOKOŁOWSKI A.W. 1965. Notatki florystyczne z Puszczy Augustowskiej. Fragm. Flor. Geobot. 11(1): 23-26. (in Polish with English summary)

SOKOŁOWSKI A.W. 1969. Zespoły leśne nadleśnictwa Balinka w Puszczy Augustowskiej. Monogr. Bot. 28: 1-79. (in Polish with English summary)

SOKOŁOWSKI A.W. 1981a. Flora roślin naczyniowych Białowieskiego Parku Narodowego. Fragm. Flor. Geobot. 27(1-2): 51-131. (in Polish with English summary)

SOKOŁOWSKI A.W. 1985a. Roślinność rezerwatu Jesionowe Góry w Puszczy Knyszyńskiej. Parki Nar. i Rez. Przyr. 6(1): 11-32. (in Polish with English summary)

SOKOŁOWSKI A.W. 1988a. Carex disperma Dewey. In: Jasiewicz A. (ed.), Materiały do poznania gatunków rzadkich i zagrożonych Polski. I. Fragm. Flor. Geobot. 33(3-4): 310-314 (in Polish with English summary)

SOKOŁOWSKI A.W. 1988b. Carex loliacea L. In: Jasiewicz A. (ed.), Materiały do poznania gatunków rzadkich i zagrożonych Polski. I. Fragm. Flor. Geobot. 33(3-4): 323-327 (in Polish with English summary)

SOKOŁOWSKI A.W. 1990b. Flora roślin naczyniowych Wigierskiego Parku Narodowego. Parki Nar. Rez. Przyr. 9(4): 5-84. (in Polish with English summary)
SOKOŁOWSKI A.W. 1995a. Flora roślin naczyniowych Puszczy Białowieskiej. Białowieski Park Narodowy, Białowieża, pp. 273. (in Polish with English summary)

SOKOŁOWSKI A.W. 1995b. Rośliny naczyniowe Puszczy Knyszyńskiej. Parki Nar. i Rez. Przyr. 14(1): 3-84. (in Polish with English summary)

SZAFER W., KULCZYŃSKI S., PAWŁOWSKI B. 1953. Rośliny Polskie. Opisy i klucze do oznaczania wszystkich gatunków roślin naczyniowych rosnących w Polsce bądź dziko, bądź też zdziczałych lub częściej hodowanych. PWN, Warszawa, pp. xxviii +1020 . (in Polish)

TOIVONEN H. 1981. Spontaneous Carex hybrids of Heleonastes and related sections in Fennoscandia. Acta Bot. Fennica 116 : $1-51$.

TOIVONEN H., TIMONEN T. 1976. Perigynium and achene epidermis in some species of Carex, subg. Vignea (Cyperaceae), studied by scanning electron microscopy. Ann. Bot. Fenn. 13: 49-59.

TRASS H., VELLAK K., INGERPU N. 1999. Floristical and ecological properties for identifying of primaeval forests in Estonia. Ann. Bot. Fenn. 36: 67-80.

ZAJAC A. 1978. Atlas of distribution of vascular plants in Poland (ATPOL). Taxon 27(5-6): 481-484.

ZAJĄC A., ZAJĄC M. (eds). 2001. Atlas rozmieszczenia roślin naczyniowych w Polsce. Distribution Atlas of Vascular Plants in Poland. Labor. Comp. Chorology, Inst. Bot., Jagiellonian Univ., Kraków, pp. xii + 715. (in Polish and English)

ZARZYCKI K., SZELĄG Z. 2006. Red list of the vascular plants in Poland. In: Mirek Z., Zarzycki K., Wojewoda W., Szeląg Z., Red list of plants and fungi in Poland. W. Szafer Inst. Bot., Polish Acad. Sci., Kraków, pp. 11-20. 